\title{
Panchatantra: Its impact on Perso-Arabic Literature
}

\author{
Dr. Abdul Majeed Nadwi \\ Head, Deptt. Of Arabic Gauhati University, Ghy- 14
}

\begin{abstract}
The Panchatantra (Five Principles) is an ancient Indian inter-related collection of animal fables in verse and prose, in a frame story format. The original Sanskrit work, which some scholars believe was composed in the 3rd century BCE, is attributed to Vishnu Sharma. It is based on older oral traditions, including "animal fables that are as old as we are able to imagine", including the Buddhist Jataka Tales. It is "certainly the most frequently translated literary product of India", and these stories are among the most widely known in the world.
\end{abstract}

There are recorded over two hundred different versions known to exist in more than fifty languages, and three-fourths of these languages are extra-Indian. As early as the eleventh century this work reached Europe, and before 1600 it existed in Greek, Latin, Spanish, Italian, German, English, Old Slavonic, Czech, and perhaps other Slavonic languages. Its range has extended from Java to Iceland... [In India,] it has been worked over and over again, expanded, abstracted, turned into verse, retold in prose, translated into medieval and modern vernaculars, and retranslated into Sanskrit. And most of the stories contained in it have "gone down" into the folklore of the story-loving Hindus, whence they reappear in the collections of oral tales gathered by modern students of folk-stories.

Thus it goes by many names in many cultures. In India, it had at least 25 recensions, including the Sanskrit Tantrākhyāyik $\bar{a}$ and inspired the Hitopadesha. It was translated into Middle Persian in 570 CE by.This became the basis for a Syriac translation as Kalilag and Damnag and a translation into Arabic in 750 CE by Persian scholar Abdullah Ibn al-Muqaffa as Kalīlah wa Dimnah. A New Persian version from the 12th century became known as Kalīleh o Demneh and this was the basis of Kashefi's 15th century Anvār-e Soheylī (The Lights of Canopus). The book in different form is also known as The Fables of Bidpai (or Pilpai, in various European languages) or The Morall Philosophie of Doni.

The Panchatantra is an inter-woven series of colourful fables, many of which involve animals exhibiting animal stereotypes. According to its own narrative, it illustrates, for the benefit of three ignorant princes, the central Hindu principles of nit $t$. While nit $i$ is hard to translate, it roughly means prudent worldly conduct, or "the wise conduct of life".

Apart from a short introduction — in which the author, Vishnu Sarma, is introduced as narrating the rest of the work to the princes - it consists of five parts. Each part contains a main story, called the frame story, which in turn contains several stories "emboxed" in it, as one character narrates a story to another. Often these stories contain further emboxed stories. The stories thus operate like a succession of Russian dolls, one narrative opening within another, sometimes three or four deep. Besides the stories, the characters also quote various epigrammatic verses to make their point.

The five books are called:

- Mitra-bheda: The Separation of Friends (The Lion and the Bull)

- Mitra-lābha or Mitra-samprāpti: The Gaining of Friends (The Dove, Crow, Mouse, Tortoise and Deer)

- Kākolūkìyam: Of Crows and Owls (War and Peace)

- Labdhapranāśam: Loss Of Gains (The Monkey and the Crocodile)

- Aparīkșitakārakam: Ill-Considered Action / Rash deeds (The Brahman and the Mongoose)

\section{Persian and Arabic versions of Panchatantra}

The Persian Ibn al-Muqaffa' translated the Panchatantra (in Middle Persian: Kalilag-o Demnag) from Middle Persian to Arabic as Kalīla wa Dimna. This "is considered the first masterpiece of Arabic literary prose." By the time the Sanskrit version migrated several hundred years through Pahlavi (Middle Persian) into Arabic, some important differences arose.

The introduction and the frame story of the first book changed.

The two jackals' names transmogrified into Kalila and Dimna. Perhaps because the first section constituted most of the work, or because translators could find no simple equivalent in Zoroastrian Pahlavi for the concept expressed by the Sanskrit word 'Panchatantra', the jackals' names, Kalila and Dimna, became the generic name for the entire work in classical times. 
After the first chapter, Ibn al-Muqaffa' inserted a new one, telling of Dimna's trial. The jackal is suspected of instigating the death of the bull "Shanzabeh", a key character in the first chapter. The trial lasts for two days without conclusion, until a tiger and leopard appear to bear witness against Dimna. He is found guilty and put to death.

Ibn al-Muqaffa' inserted other additions and interpretations into his "re-telling" book "Kalīlah wa Dimnah". The political theorist Jennifer London suggests that he was expressing risky political views in a metaphorical way. (Al-Muqaffa' was murdered within a few years of completing his manuscript). London has analyzed how Ibn al-Muqaffa' could have used his version to make "frank political expression" at the 'Abbasid court.

Al-Muqaffa' also changed the characterization of some animals, perhaps to have local types which his readers would recognize. For instance, the crocodile in the fourth chapter is changed to a tortoise, and the mongoose into a weasel. The Brahman is described as a "hermit".

He begins each chapter of Kalila wa Dimna with a guiding frame-story theme that suggests key aspects of leadership:

1. One should always be wary if one friend accuses another of crime;

2. (Added chapter) Truth will be revealed, sooner or later;

3. Cooperation among friends is vital to their survival;

4. Mental strength and deceit are stronger in warfare than brute force;

5. One must be careful not to betray friends, especially guarding against one's own tendencies towards foolishness; and

6. One should be wary of hasty judgements.

\section{Origin and Function}

In the Indian tradition, The Panchatantra is a nîtiśāstra. Nîti can be roughly translated as "the wise conduct of life" and a śästra is a technical or scientific treatise; thus it is considered a treatise on political science and human conduct. Its literary sources are "the expert tradition of political science and the folk and literary traditions of storytelling". It draws from the Dharma and Artha śāstras, quoting them extensively. It is also explained that nit $i$ "represents an admirable attempt to answer the insistent question how to win the utmost possible joy from life in the world of men" and that niti is "the harmonious development of the powers of man, a life in which security, prosperity, resolute action, friendship, and good learning are so combined to produce joy".

The Panchatantra shares many stories in common with the Buddhist Jataka tales purportedly told by the historical Budha before his death around 400 BCE. As the scholar Patrick Olivelle writes, "It is clear that the Buddhists did not invent the stories. It is quite uncertain whether the author of [the Panchatantra] borrowed his stories from the Jätakas or the Mahäbhärata, or whether he was tapping into a common treasury of tales, both oral and literary, of ancient India." Many scholars believe the tales were based on earlier oral folk traditions, which were finally written down, although there is no conclusive evidence. In the early 20th century, W. Norman Brown found that many folk tales in India appeared to be borrowed from literary sources and not viceversa.

An early Western scholar who studied The Panchatantra was Dr. Johannes Hertel, who thought the book had a Machiavellian character. Similarly, Edgerton noted that "The so-called 'morals' of the stories have no bearing on morality; they are unmoral, and often immoral. They glorify shrewdness and practical wisdom, in the affairs of life, and especially of politics, of government." Other scholars dismiss this assessment as one-sided, and view the stories as teaching dharma, or proper moral conduct. Also:

On the surface, the Pañcatantra presents stories and sayings which favour the outwitting of roguery, and practical intelligence rather than virtue. However, From this viewpoint the tales of the Pañcatantra are eminently ethical. The prevailing mood promotes an earthy, moral, rational, and unsentimental ability to learn from repeated experience.

In the first frame story, the evil Damanaka ('Victor') wins, and not his good brother Karataka. The persistent theme of evil-triumphant in Kalila and Dimna Part One, frequently outraged readers among Jewish, Christian and Muslim religious leaders who encountered the work in translation. Some scholars believe that Ibn al-Muqaffa inserted a chapter at the end of Part One, which puts Dimna in jail, on trial and eventually to death, in an effort to assuage religious opponents of the work.

The pre-Islamic original, The Panchatantra, contains no such dogmatic moralising. As Joseph Jacobs observed in 1888, "... if one thinks of it, the very raison d'être of the Fable is to imply its moral without mentioning it.

The work has gone through many different versions and translations from the sixth century to the present day. The original Indian version was first translated into a foreign language(Pahlavi) by Borzuya in 
570CE, then into Arabic in 750. This became the source of versions in European languages, until the English translation by Charles Wilkins of the Sanskrit Hitopadesha in 1787.

\section{Early cross-cultural migrations}

The Panchatantra approximated its current literary form within the 4th-6th centuries CE, though originally written around 200 BCE. No Sanskrit texts before 1000 CE have survived. According to Indian tradition, it was written by Pandit Vishnu Sarma a sage. Buddhist monks on pilgrimage took the influential Sanskrit text (probably both in oral and literary formats) north to Tibet and China and east to South East Asia. These led to versions in all Southeast Asian countries, including Tibetan, Chinese, Mongolian, Javanese and Lao derivatives.

\section{How Borzuy brought the work from India}

The Panchatantra also migrated westwards; during the Sassanid reign of Khosru, Around $570 \mathrm{CE}$ his notable physician Borzuy translated the work from Sanskrit into the Middle Persian language, and transliterated the main characters as Karirak ud Damanak or Kalile va Demne.

According to the story told in the Shah Nama (The Book of the Kings, Pesia's late 10th century national epic by Ferdowsi), Borzuy sought his king's permission to make a trip to Hindustan in search of a mountain herb he had read about that is "mingled into a compound and, when sprinkled over a corpse, it is immediately restored to life." He did not find the herb, but was told by a wise sage of

"a different interpretation. The herb is the scientist; science is the mountain, everlastingly out of reach of the multitude. The corpse is the man without knowledge, for the uninstructed man is everywhere lifeless. Through knowledge man becomes revivified."

The sage pointed to the book Kalila, and Borzuy obtained the king's permission to read and translate the book, with the help of some Pandits.

\section{The Arabic classic by Ibn al-Muqaffa}

Borzuy's 570 CE Pahlavi translations (Kalile va Demne, now lost) was translated into Syriac. Nearly two centuries later, it was translated into Arabic by Ibn al-Muqaffa around $750 \mathrm{CE}$ under the Arabic title, Kalīla wa Dimma. After the Arab invasion of Persia (Iran), Ibn al-Muqaffa's version (two languages removed from the pre-Islamic Sanskrit original) emerged as the pivotal surviving text that enriched world literature. Ibn alMuqqaffa's work is considered a model of the finest Arabic prose style, and "is considered the first masterpiece of Arabic literary prose."

Some scholars believe that Ibn al-Muqaffa's translation of the second section, illustrating the Sanskrit principle of Mitra Laabha(Gaining Friends), became the unifying basis for the Brethren of Purity (Ikwhan alSafa - the anonymous 9th century CE Arab encyclopedists whose prodigious literary effort, Encyclopedia of the Brethren of Sincerity, codified Indian, Persian and Greek knowledge. A suggestion made by Goldziher, and later written on by Philip K. Hitto in his History of the Arabs, proposes that "The appellation is presumably taken from the story of the ringdove in Kalilah wa-Dimnah in which it is related that a group of animals by acting as faithful friends (ikhwan al-safa) to one another escaped the snares of the hunter." This story is mentioned as an exemplum when the Brethren speak of mutual aid in one risaala (treatise), a crucial part of their system of ethics.

\section{References}

[1]. Edgerton, Franklin (1924), The Panchatantra Reconstructed (Vol.1: Text and Critical Apparatus, Vol.2: Introduction and Translation), New Haven, Connecticut: American Oriental Series Volumes 2-3

[2]. Kāśīnātha Pāṇụranga Paraba, ed. (1896), The Panchatantra of Vishnu Sarman, Tukaram Javji, Google Books.

[3]. Pandit Guru Prasad Shastri (1935), Panchatantra with the commentary Abhinavarajalaxmi, Benares: Bhargava Pustakalaya (Text with Sanskrit commentary)

[4]. Tales Within Tales - adapted from the fables of Pilpai, Sir Arthur N Wollaston, John Murray, London 1909

[5]. Wilkinson (1930), The Lights of Canopus described by J V S Wilkinson, London: The Studio Limited

[6]. Rajan, Chandra (transl.) (1993), Viṣnu Śarma: The Panchatantra, London: Penguin Books, ISBN 9780140455205 (reprint: 1995$)$ (also from the North Western Family text.)

[7]. Rajan, Chandra (transl.) (1993), Vișnu Śarma: The Panchatantra, London: Penguin Books, ISBN 9780140455205 (reprint: 1995) (also from the North Western Family text.)

[8]. Olivelle, Patrick (transl.) (1997), The Pancatantra: The Book of India's Folk Wisdom, Oxford University Press, ISBN 9780192839886 (Translation based on Edgerton's Southern Family Sanskrit text.) 